\title{
The first European Games - contrasting narratives
}

\section{Hans Giessen}

Universität des Saarlandes, Saarbrücken, Germany

\begin{abstract}
The topic of my paper (i.e. the event I'm referring to) are the first European Games, held in June 2015 in Baku, Azerbaijan. These games, however, were not only the event that was an object of sports reporting but also reason to write and justify a narrative on the country and its political system.

Interestingly, the narratives were indeed quite different, even when using the same terms. I would like to show this in a comparative study, using English language newspapers from the UK and from Ireland, as well as German language newspapers from Germany, Austria, and Luxembourg. Indeed, it seems to be the country of origin that determines how Azerbaijan's political system is characterized, and not so much for example the political stance (for example, whether the very paper is to be found on the right - conservative - or on the left side of the political spectre). Also, the newspaper category does not seem to be decisive, that is, whether the very paper belongs to the group of the quality press or whether it belongs to the tabloids.

Even if all newspapers of my corpus focus on the same event, i.e. the Baku games, and, more so, all of them even use the same linguistic terms and concepts (like Azerbaijan being characterized as "authoritarian"), characterization differs dramatically. The differences correlate only on the paper's country of origin, and thus seem to depend on national narratives. Even in spite of using the same vocabulary, the stories are well opposed. For example, The Irish Times used the same (English language) concepts as the Guardian, but praised the games, whilst the Guardian denounced Azerbaijan's political system to an extent that even its reporter is banned from Azerbaijan. Similarly, German and even more so Austrian papers deplore Azerbaijan's political system, whilst the Luxemburg press praises the system for these well-organized games.
\end{abstract}

Keywords: Austria, English speaking countries in Europe, European Games, framing, German speaking countries in Europe, Germany, Ireland, Luxembourg, United Kingdom, values

\section{Introduction}

The first European Games were opened on Friday, 12. June, 2015, in Baku, the capital of Azerbaijan. They lasted until 28. June, 2015. As this was the creation of a new high profile sports event that aimed to unite the continent - of course in 
regard of sports, but also as a media event, political discussions were intense and indeed controversial.

The Games thus were not only an event that was an object of sports reporting but also a reason to write and justify a narrative about the host country and its political system. Thus these first European games seem to have the potential for a comparative analysis of the coverage within different European media. It was especially looked for the newspaper coverage in different countries with one and the same language, respectively. Since the pluricentric languages in Europe are German and English, this author decided to use papers from German and English speaking countries as an opportunity for such an analysis.

The focus of this study thus lies not on sports but on the implications of the Games. The corpus consists of three papers from Austria, three quality and three regional papers from Germany, and four papers Luxembourg (for the German language papers), and of three UK and two Ireland papers (for the English language papers). All in all, it includes 18 papers both of national and regional scope, from high quality papers to tabloids, with a minimum circulation of 100000 .

Also, as reporting was thought to shift towards sports in the course of the Games, the corpus was limited to papers from the week of the opening ceremony (Monday, 8. June, 2015, until Saturday, 13. June, 2015).

Interestingly, the narratives about Azerbaijan were quite different. Indeed, it seems to be the country of origin of the respective newspaper that determines how Azerbaijan's political system is characterized, and not so much for example the political stance of the very paper (whether the very paper is to be found on the right - conservative - or on the left side of the political spectrum), nor is the newspaper category decisive, that is, whether the very paper belongs to the group of the quality press or whether it belongs to the tabloids.

Even if all newspapers of my corpus focus on the same event, i.e. the Baku Games, and, more so, all of them even use the same linguistic terms and concepts (like Azerbaijan being characterized as "authoritarian" and "repressive"), characterization differs dramatically. As said, it seems that these differences can only be explained with the paper's country of origin, and thus seem to depend on national narratives. Even in spite of using the same vocabulary, the narratives might even be antagonistic. For example, The Irish Times used the same (English language) concepts as the Guardian, but praised the games, whilst the Guardian denounced Azerbaijan's political system to an extent that even its reporter is banned from Azerbaijan. Similarly, Germany's and even more so Austria's papers deplore Azerbaijan's political system, whilst the Luxembourg press praises the system for these well-organized games. 


\section{Discourses}

In the beginning, a discourse analysis was conducted with the goal to show whether and how much coverage and evaluation of the European Games in Baku differs in the respective countries. In order to do so, we look at linguistic and argumentative schemes that usually tend to derive from specific patterns of argumentation (Cartier, 1998; Sarasin, 2006, p. 24). Argumentation patterns reduce the possibilities of discourse to certain word combinations since lexicalization of communicative concepts is limited (Gibbs \& Gonzales, 1985). On the other hand, it is precisely because of the everyday understanding and explanation strategies that such a study can be used in order to work out the patterns that are used in different countries.

\subsection{German language papers}

The classification of a European media event is ideally met in Luxembourg. In Luxemburger Wort, reports about the event appear in advance on the title page. The two sports sites even get their own head design. The coverage is friendly to euphoric. For example, on 12. June, 2015, Luxemburger Wort writes: "European Games in Baku. A spectacular opening ceremony." This kind of reporting is shared by the other papers of the country. The Tageblatt of June 13, 2015, for example, dealt with the costs of the opening ceremony, but put it in a rather positive light: "Paddling, not mess."

Papers in Germany report significantly different. In general, they have a negative attitude towards the event. In some cases this leads to totally avoiding coverage beyond the sportive aspects. Most regional papers refrain from writing about the European Games on their front pages; in these papers, even the opening ceremony is covered only in the sports section or in sections that refer to human interest stories, in these cases mainly referring to the appearance of 'Lady Gaga' at this ceremony. The restraint is indirectly justified in the headlines: it is just a "little Olympics,"3 as the Rheinpfalz headlines on 12. June, 2015 on a page entitled Panorama, or "Olympic Games light,"4 as titled by Aachener Nachrichten on 13. June, 2015 on the first page of its sports section, not mentioning the event in other parts of the paper. There are few indications on why this is done; if they appear,

\footnotetext{
1 „Europaspiele in Baku. Eine spektakuläre Eröffnungszeremonie“.

2 „Klotzen, nicht kleckern“.

3 „Klein Olympia“.

4 „Olympische Spiele light“.
} 
however, they indicate a problematic "political scent"5 (as with Rheinpfalz in the continuation of the article's title), that seems to be so questionable.

Refraining seems to be what not only most conservative papers did, but also papers that reach far into the liberal and left spectrum, even in the sports section relying only on the news agencies, as applies for Die Welt (on the conservative side), but also for Berliner Zeitung, or Süddeutsche Zeitung (on the left). Other newspapers, however, explicitly address political issues. Der Tagesspiegel reported on 9. June, 2015: "Before the European Games in Baku start: Bundestag wants to denounce human rights situation in Azerbaijan." ${ }^{\prime \prime}$ The following day, Frankfurter Allgemeine Zeitung reported: "European Games in Baku: The Big Show of the President," with several subheadings, including "Increasing Repression in Azerbaijan.""

Neues Deutschland, the socialist paper from the very left, starts coverage the same way. The headline of 8th June, 2015 was: "Exile journalist calls Europe games in Baku a 'PR show for a totalitarian country'."'

The coverage of the quality newspapers from Austria corresponds to the coverage that has been observed in Germany: It is exclusively critical in regard of the host country as well as the first European Games itself. Der Standard wrote on 12th June, 2015: "European Games in Azerbaijan: Negative Advertising for Baku." ${ }^{10}$ The political editors even felt compelled to write a comment whose heading summarizes the tendency: "Azerbaijan has undercut its lousy level of human rights in the past three years." ${ }^{11}$ Similarly, Die Presse headlined on 12. June, 2015: "European Games: A sporty question of meaning." 12 No Austrian newspaper was seen to a softening of these negative political positions. Only in the sports section reporting was neutral and informed soberly about sporting events.

\subsection{English language papers}

In the United Kingdom too, reporting is in line with this pattern. The Independent headlined on 12th June, 2015: "Baku European Games 2015: Sport and politics have become a poisonous mix we can no longer ignore." The background of this

5 „politische Note“ („Klein-Olympia mit politischer Note“).

${ }^{6}$,Vor den Europaspielen in Baku: Bundestag will Menschenrechtslage in Aserbaidschan anprangern".

7 „Europa-Spiele in Baku: Die große Show des Präsidenten“.

8 „Zunehmende Repression in Aserbaidschan“.

9 „Exiljournalist nennt Europaspiele in Baku ,PR-Show für ein totalitäres Land““.

${ }^{10}$ „Europaspiele in Aserbaidschan: Negativwerbung für Baku“.

${ }^{11}$ „Aserbaidschan hat sein lausiges Niveau an Menschenrechten in den vergangenen drei Jahren noch unterboten".

12 „Europaspiele: Eine sportliche Sinnfrage“. 
is that a British journalist from the Guardian has been deprived of accreditation because of his negative reporting. This led to a solidarizing effect and to a reporting that is by no means less negative to the Austrian one.

On the other hand, Ireland (the home country of the incumbent President of the European Olympic Committee, Pat Hickey (a fact that might be of some importance in this respect) is setting its own priorities. In fact, The Irish Times forms with the Guardian an editorial working association especially in regard of joint foreign correspondents (Guardian service). Since The Irish Times now can not rely on the Guardian's Azerbaijani reporter any more, reporting is limited. This, on the other hand, seems to give new opportunities to the newspaper, as it obviously seeks a less critical and anti position. First, on 11th June, 2015, the paper explains why it will be difficult to report: "Azerbaijan government ban The Guardian from Baku Games." Nevertheless, the home office is gathering more reports, and it is noticeable that and how quickly it turns the focus away from the problematic political situation. On 12. June, 2015, The Irish Times writes: "European Games kick off in Baku as focus moves to sport," and analogously in another article: "Let the European Games begin even as controversy looms large."

\section{Linguistic realizations}

Expressions like 'authoritarian' (or 'repressive,' for that matter) are almost schematically linked to certain country names. Collocative are country names like 'Russia' - and 'Azerbaijan.' A Google search for "Azerbaijan NEAR repressive" leads to half a million hits (7. December, 2018). Almost inevitably, this combination is also found in the newspapers of the corpus.

The Guardian as well as The Irish Times report on 11th June, 2015 of the Guardian journalist's accreditation ban in an article (that the Irish newspaper has published in accordance to the sharing contract with the Guardian) and in which, on that day, obviously substantiated and quite understandable, the words of "government repression" show up. In the further reporting, the collocating of the political descriptor with the name of the country takes place almost automatically. The Irish Times speaks in the text "Let the European Games begin even as controversy looms large" of 12th June, 2015 of "a repressive petro-financed mafia state." The Independent uses the potential of this linguistic and content-related connection on 12th June, 2015, even for a new word creation: "the Repression Games" (instead of "the European Games").

All German language newspapers of the corpus, too, regularly link the country name Azerbaijan with these political descriptors. Examples are "state 
repression"13 from Tagesspiegel of 9. June, 2015, or "[i]ncreasing repression in Azerbaijan" ${ }^{14}$ in Frankfurter Allgemeine Zeitung of 10. June, 2015. Also from Frankfurter Allgemeine Zeitung are the examples "the repressions of the Azerbaijani regime" 15 or the series "Swank, propaganda, arrests and repressions," of 13. June, 2015.

A quote as "President Ilham Aliyev, who, since 2003, rules his country in an authoritarian and increasingly repressive ruled way"17 from Frankfurter Allgemeine Zeitung of 11. June, 2015, refers to the second term of this word field. 'Azerbaijan' and 'authoritarian' seem to collocate just as often as 'Azerbaijan' and 'repressive'. The search for "Azerbaijan NEAR authoritative" yields even more hits than for the descriptor "repressive.' In addition, there is the term "autocratic," which is used by the Independent, for example, on 12. June, 2015, and the Guardian speaks on 11th June, 2015 about "the autocratic government of the president, Ilham Aliyev."

Again, these schematisms can be found literally in all German examples, such as the regional daily Die Rheinpfalz, which speaks of a "state organized in an athoritarian way" ${ }^{18}$ on 12th June, 2015, or Westdeutsche Allgemeine Zeitung, discussing "the authoritarian-led Government of President Ilham Aliyev," 19 13. June, 2015. In Frankfurter Allgemeine Zeitung of 12. June, 2015, we see a variation such as "an autocratic regime," ${ }^{20}$ and Tagesspiegel speaks on 9. June, 2015 about "Azerbaijan, which is authoritarian ruled by President Ilham Aliyev." 21 - The same applies to literally all papers from Austria. Die Presse, on 12th June, 2015, has a report on "the authoritarian president, Ilham Aliyev." 22

Even more so, the link between the political system of Azerbaijan and these terms are also found in newspapers from countries that do not value the Games and the political system of the hosting country as problematic and that tend to report positively. An example from Luxembourg is the article of Tageblatt from 12th June, 2015, whose headline "Jeff Henkel is our flag bearer in Baku"23 already

\footnotetext{
13 „staatliche Repression”.

14 "Zunehmende Repression in Aserbaidschan“.

15 „die Repressionen des aserbaidschanischen Regimes“.

16 „der Protz, die Propaganda, die Verhaftungen und Repressionen“.

17 „Präsident Ilham Alijew, der sein Land seit 2003 autoritär und zunehmend repressiv regiert“.

18 ,autoritär geführten Staat“.

19 „die autoritär geführten Regierung von Staatspräsident Ilham Aliyev“.

${ }^{20}$ „ein autokratisches Regime“.

${ }^{21}$ "Aserbaidschan, das von Präsident Ilham Alijew autoritär regiert wird“.

22 „Vom autoritären Präsidenten, Ilham Alijew“.

23 „Jeff Henkels Fahnenträger in Baku“.
} 
demonstrates that a criticism of the Games is certainly not in mind here. Nevertheless, there are statements in this article that use the linguistic schemata mentioned, such as when speaking of "the authoritarian-led government." 24

\section{Same expressions, different positions}

Still, the Games are covered in a contrasting way, evidently correlated not so much with the respective newspaper's political stance, but according to the country of origin. As said, in the German-speaking world, the newspapers are always very critical, both in Germany proper, as well as in Austria, where papers are particularly negative towards the hosting country. By contrast, the coverage in the German-speaking Grand Duchy of Luxembourg is extremely positive and approving.

The situation is similar in the English-speaking press. All papers from the United Kingdom, without restriction, report in a decidedly critical way about the Games and the political system of Azerbaijan. There is literally not a single positive article on the European Games to be found in the British newspapers.

The eviction order of the Guardian reporter also affected the Irish Times, which is supplied by the Guardian Service. But here the rejection of the event and the policies of Azerbaijan is not so evident - and then, very fast, turns to be much more positive.

It is important to hint on the fact that all newspapers examined are of West and Central European origin. This means they are read in countries that, at least since the Second World War (i.e. for seventy years, more than two generations) are democratic. Still, in regard of valuing Azerbaijan's political system, they oppose each other diametrically. While there is a radical rejection of the political system and, as a consequence, the European Games to be found in Austria, the United Kingdom, and in Germany, others welcome the event and even want to ask Azerbaijan to again organize the next games in four year's time because the organization was so impressive (Ireland and even more clearly Luxembourg). A phrase such as Luxembourg's Tageblatt's "It is also a fact that Baku sets and will set very high standards. [...] Perhaps the EOC could ask the President of Azerbaijan, Ilhan Aliyev, for the second edition to be held in his country as well ..." ${ }^{25}$ cannot be imagines in Austria or the UK! - High Standards is, of course, a clear and strong

24 „die autoritär geführten Regierung“.

25 „Fakt ist auch, dass Baku sehr hohe Standards setzt und setzen wird. [ ... ] Vielleicht könnte das EOC den Präsidenten Aserbaidschans, Ilhan Aliyev, darum bitten, auch die zweite Ausgabe in seinem Land stattfinden zu lassen ...". 
positive expression. So there is nothing to be felt here from the criticism of the political system and the president, on the contrary. In Luxembourg you would not oppose another Games in Azerbaijan, you even consider this to be the very best possible option. This is a position diametrically opposed to everything you would read in Britain, Germany or Austria.

Despite these different positions, the linguistic schemes are absolutely comparable. All papers use the same expressions, again regardless of their political position - and even regardless their country of origin. Obviously, it is clear to everyone that Azerbaijan is an autocratic governed country, which contradicts the common political values of all countries included in this survey. Moreover, these common values clearly do lead to a common language. However, this evidently does not lead to a common position, positions being indeed absolutely contrary.

\section{Conclusions}

Obviously, different positions are possible despite identical linguistic schemes. These observations thus can be seen as a contribution to the debate on the effectiveness of the framing theory.

Framing theorists suggest that words determine the way in which we think, as every word invokes a frame in the recipient's mind and, in turn, guide the perception of whatever is the issue, most time without even being aware of (Goffman, 1974; Lakoff, 2004; Lakoff \& Johnson, 1980). The question, however, is whether we are able to think beyond frames. Theoretically, this seems to be the case, since without development or progress, no new idea would be possible. In framing theory this is accepted insofar as it might be possible to become conscious of the reasoning and decision-making, but this only happens if one is intensively involved with topics and has background knowledge.

The finding of this study, however, suggest that while linguistic frames are so important that they cannot be avoided, and indeed are used by literally all newspapers of this corpus, they seem to determine at least the paper's stance to a lesser extent than frames of national public opinions.

\section{References}

Chartier, R. (1998). Le monde comme représentation. In Ch. Roger (Ed.), Au bord de la falaise. L'histoire entre certitudes et inquiétude, (pp. 76-86). Paris: Albin Michel.

Gibbs, R. W. \& Gonzales, G. P. (1985). Syntactic Frozenness in Processing and Remembering Idioms. Cognition, 20(3), 243-259. 
Goffman, E. (1974). Frame Analysis. Boston: Northeastern University Press.

Lakoff, G. (2004). Don't Think of an Elephant: Know Your Values and Frame the Debate. Chelsea: Chelsea Green.

Lakoff, G. \& Johnson, M. (1980). Metaphors We Live By. Chicago: University of Chicago Press.

Sarasin, P. (2006). Geschichtswissenschaft und Diskursanalyse. Frankfurt/M: Suhrkamp. Wehling, E. (2016). Politisches Framing: Wie Eine Nation Sich Ihr Denken Einredet - Und Daraus Politik Macht. Köln: von Halem. 